\title{
Zambrano's poetic reason in the light of Frankfurtian Critical Theory
}

The members of the Institut für Sozialforschung ${ }^{1}$ or Institute for Social Research, better known as the Frankfurt School, are praised for having identified that instrumental reason lies at the very foundation of modernity. Max Horkheimer, Theodor Adorno, Herbert Marcuse, and Walter Benjamin all developed a critique of society and its established patterns of rationality known as Critical Theory ${ }^{2}$.

Although there is much that separates the thought of the Frankfurt School from that of María Zambrano, there are also significant parallels which deserve to be explored. Specifically, they not only have in common the object of their critique, that is, the dominance of reason, but they also share the same starting premise: the irrationality behind the façade of rationalism. Moreover, they all embark upon the same task, namely, the pursuit of an alternative framework of rationality.

I must emphasize, however, that by this I do not mean to suggest that Zambrano was influenced by the Frankfurt School and that she developed her poetic reason as a result of such influence ${ }^{3}$. Instead, by drawing attention to the meaningful parallels between poetic reason and Frankfurtian Critical Theory, this paper aims to, first, recontextualize Zambrano's thought in reference to $20^{\text {th }}$ century political philosophy -with specific reference to the Frankfurt School-, and, second, to reempower her discourse, but retrieving it from the realms of philosophy and mysticism and reclaiming its political content.

There is no doubt of the substantial differences between the backgrounds of Zambrano and the members of the Institut. Whereas the Frankfurt School attempted to incorporate and update Marxist and Freudian theories, Zambrano, on the other hand, espoused what Ana Bundgård describes as a spiritual liberalism (see 2005: 21-41) and was more deeply influenced by Jung than by Freud, of whom she was very critical, as seen in "El freudismo, testimonio del hombre actual" (1940).

\footnotetext{
${ }^{1}$ Horkheimer, Adorno, Marcuse, and even Pollock form the core of the Institut. Fromm, Benjamin, Neumann, and Kirchheimer are also integral members, although their focus and association with the School differs from the members mentioned above, and as a result are sometimes described as being on the periphery. Habermas heads the second wave of this current of thought (for a brief history and reflection on the term "Frankfurt School" see Heller, 2002: 207; see also Gómez Sánchez, 2004: 225-26).

${ }^{2}$ Despite the fact that initially "critical theory" denoted the work of the Institut and it is still closely associated with it, the use of this label has expanded to describe work of a critical nature, although quite varied in character, intention, and substance. It is with its original meaning, in reference to the Frankfurt School, that this term will be used throughout this paper, which is why henceforth it will be used in capitals.

${ }^{3}$ It should be noted that Zambrano did enter into contact with their thought. Evidence of this is her possession of an edition of a compilation of Benjamin and Adorno's letters -Allemands. Une série de letters (1979)- and Adorno's Sulla metacritica della gnoseologia (1964b), which can be found in the contents of her personal library, now kept at the Fundación María Zambrano. Incidentally, Zambrano's long trajectory of exile is visible in the language of the titles of the books of her personal collection, which provide a glimpse of her numerous relocations and cultural immersions. More to the point, they are also evidence of her familiarity, although limited, with Critical Theory.
} 
Nevertheless, despite these differences, in both cases their thought remains firmly rooted in the events of $20^{\text {th }}$ century history. Confronted with the incongruities and the injustices of totalitarian ideology, as well as with the destruction, displacement, death, and exile on an unprecedented scale brought about by the First and Second World Wars, the unreason behind these events became evident and a new form of reason had to be sought. This is the crisis these authors identified and the challenge they faced. Hence, the critique of reason of the Frankfurt School has been profoundly marked by the two World Wars and their own experience of exile. This is also true of Zambrano's critique, which in addition to this- was greatly influenced by her own experiences during the Spanish Civil War.

Their historically rooted critique of rationality is not the only link between Zambrano's thought and Frankfurtian Critical Theory. There are also significant similarities between their aims, style and epistemological stand points and the alternative frameworks of rationality they respectively developed. This is why this paper will start by establishing a comparison between Critical Theory and Zambrano's approach to reason so as to reveal such similarities. Then, it will conclude by reassessing the political component of Zambrano's thought in the light of this comparison.

\section{Aims and scope of Critical Theory and Poetic Reason}

The first question which needs to be addressed is: what is Critical Theory? Critical Theory emerged in reaction to the new challenges posed by advanced capitalist society. The rise of the welfare state as well as the rapid economic and social developments which took place in Europe and the United States after Wold War Two resulted in profound changes in the relationship between production and consumption. This led to typically Marxist concepts such as proletariat, class consciousness, and class struggle becoming obsolete and inapplicable. Instead, the Frankfurt School most of whose members had emigrated to the United States and were confronted with a first-hand experience of this new form of capitalism- argued that the figure of the proletariat had been replaced by the consumer and they identified the mass as the new social force. Their analysis incorporated not just economic factors, but also psychological and cultural insights which led them to denounce the new forms of control and alienation that resulted from neo-capitalism. The result was a complex and transdisciplinary theory whose critique targeted mass society, consumerism, and the culture industry. However, instead of addressing socio-economic and political problems directly, its critique was directed against the specific rationality at the foundation of neo-capitalist society, that is, instrumental reason. Such a critique is most clearly developed in Horkheimer's Eclipse of Reason (1947b) and Marcuse's One-Dimensional Man (1964).

The phrase instrumental reason refers to the framework of rationality according to which each object and each action is conceived and treated as a means and not as an end in itself. Although the concept was already formulated in Horkheimer's Eclipse of Reason (1947b), the phrase "instrumental reason" first appeared in Zur Kritik der instrumentellen Vernunft (1967), that is, the German 
translation of Horkheimer's English original ${ }^{4}$. Influenced by Max Weber's concept of the "iron cage", Horkheimer argues that reason, as has been known and exercised since the Enlightenment, is ruled by exploitation, productivity, and profitability criteria which have become ends in themselves (Horkheimer, 1973: 21). This rationality has equated utility with reason, ultimately resulting in the subjugation of nature and the individual. More specifically, instrumental reason describes the use of reason with the purpose of social control. That is why, far from being the kind of interpersonal, critical, and reflexive reason which would encourage the development of the individual and of the society s/he inhabits, it constitutes a form of rationality which, in fact, proves to be irrational insofar as it leads to destructive consequences. As Stephen Bronner explains, for the Frankfurt School, "technology generated under capitalism and its peculiar form of instrumental or scientific thinking increasingly undermines the reflective exercise of subjectivity. Moral judgment is understood as becoming increasingly subordinate to instrumental thinking, and, as a consequence, individuals appear threatened with the loss of their capacity for normative judgment" (2002: 223). It is because of this threat to the normative judgement of the individual and its consequences that instrumental reason is judged to be essentially irrational. In other words, it is an assessment made on moral grounds ${ }^{5}$.

Like the Frankfurt School, Zambrano elaborates a sharp criticism against the dominance of reason and the insufficiency of reason alone. A critique of the rationality of the Enlightenment and its material consequences can already be observed in her first book, Horizonte del liberalismo (1930). From then onwards, this critique is present in numerous publications, such as Los intelectuales en el drama de España (1937), Filosofía y poesía (1939), El freudismo, testimonio del hombre actual (1940), La confesión, género literario y método (1943), La agonía de Europa (1945), ${ }^{6}$ El hombre y lo divino (1955), Persona y democracia (1958), and La tumba de Antígona (1967), to name but a few.

Situating her discussion within the context of Western philosophy and particularly the heritage of the Enlightenment, in Horizonte del liberalismo (1930) Zambrano rejects this idealized form of rationality, that is, rationalism, as insufficient and treacherous. As Mari Paz Balibrea succinctly puts it, "What Zambrano is attempting in 1930 around the concept of 'nuevo liberalismo' is a timely critique of modernity that goes to the root of Enlightenment as a critique of 'la razón clásica,' or logical reason" (2005: 13). There, Zambrano denounces rationalism as established upon pure reason alone, making reason rigid and immobile (1930: 36). According to her, this rationalism is at the root

\footnotetext{
${ }^{4}$ Although the term "instrumental reason" was first used by Horkheimer, it is grounded on Max Weber's concept of the "iron cage" to refer to the dead-end of modern reason, a reason which is tightly limited by regulations and focuses only on the ends, losing sight of the means. As David Rasmussen explains, "Weber coined the term Zweckrationalität, purposive-rational action. Reason, devoid of its redemptive and reconciliatory possibilities, could only be purposive, useful and calculating" (2006: 266).

${ }^{5}$ For the Frankfurt School and Adorno, in particular, these destructive consequences have materialized more clearly in the moral atrocities of Auschwitz (see Adorno, 2003: 19-36).

${ }^{6}$ For a comparison of Zambrano and Benjamin's thought regarding the origins of European violence, please see David Soto Carrasco's article “Historia y violencia: Walter Benjamin y María Zambrano” (2010: 417-34).
} 
of liberalism as well as of communism. It is the rigidity at the core of rationalism that, in her view, has led to dangerous moral consequences in both political systems.

She condemns the economic consequences that rationalist liberalism has led to and identifies the lack of an economic democracy as the main hurdle in achieving the promises of liberalism. Hence, she concludes that "Los postulados espirituales del liberalismo no pueden realizarse con la economía liberal" (1930: 124). Consequently, for her, rationalist liberalism has resulted in what she perceived as the social, political, psychological and metaphysical disintegration of her day, that is, to a profound sense of crisis (1930: 107-08).

The inescapable conclusion is that the rational principles of the Enlightenment have led to outcomes which are neither rational nor desirable. One of the most serious consequences of this is that the individual functions as both a subject and an object of this rationality, even becoming its victim. Zambrano encapsulates the consequences of this type of reason in the concept of sacrificial history, which -as argued in Los intelectuales en el drama de España (1937)- consists of the development of history at the cost of human sacrifice (1977: 16). In fact, her work as a whole can be described as a reaction against the tyranny of reason and the pursuit of an alternative to it.

Although Zambrano did not specifically use the term "instrumental reason", she was critical of its presence in human life. She condemned instrumentalization in a literal, material sense, in reference to the proliferation of instruments and technology. An analysis reminiscent of the critique of the Frankfurt School, can be found in "La 'Guía', forma del pensamiento" (1943), where she states the following:

Mientras la vida se llenaba de instrumentos técnicos, de maravillas mecánicas, de cachivaches de todas clases, el alma y el corazón quedan vacíos, y las horas, al ser liberadas del trabajo opresor, transcurren más oprimidas todavía, porque están sujetas a la terrible opresión de la vaciedad de un tiempo muerto. La quietud se hacía imposible. Paralelamente a los medios de comunicación y a las posibilidades de ir y venir, el vacío se adueña de las vidas (2004a: 74-75).

No matter how useful the instruments, she insists on their insufficiency, for the problem of the incompleteness of human birth cannot be solved with material objects (2004a: 76-77). As explained in Horizonte del liberalismo, at the root of the problem, Zambrano identifies the nineteenth century ideal of progress, which encompasses scientific and technological advances, but which in her view proved to be ineffective with regards to moral or political progress (1930: 62-63). This is why a sense of crisis permeates Zambrano's understanding of modernity, which -as with Critical Theory- stems from the absolutism of reason.

Thus, the concept of reason plays a pivotal role in Zambrano's critique, but also in Critical Theory, as they all consider that the ultimate cause for the ills affecting society lies in its defective framework of rationality. Axel Honneth draws the reader's attention to the fact that despite the different vocabulary used by the various members of the Instutitut -"irrational organization" (Horkheimer); "administered world" (Adorno); "one-dimensional society", "repressive tolerance" 
(Marcuse); and "colonization of the social life-world" (Habermas)- they all refer to a deformed rationality in contrast to a presupposed "intact" rationality which would provide individuals the opportunity for self-actualization (see Honneth, 2004: 338-39).

In the case of Zambrano, one of her the phrases which best encapsulates the limitations and excesses of reason is "la soberbia de la razón", that is, the arrogance of reason, because -as she puts it in Pensamiento y poesía en la vida española (1939)- "los breves pasos en que hemos acompañado a la razón en su caminar por nuestro angosto mundo de Occidente, son suficientes, creo yo, para poder advertir que la razón se ensoberbeció" (1939: 18). This is a topic that she continues to tackle in La Confesión: Género literario (1943) ${ }^{7}$, where she is critical of a reason which, based on self-interest criteria, does not take life into account (2004b: 21). This is why she states that "el drama de la Cultura Moderna ha sido la falta inicial de contacto entre la verdad de la razón y la vida" (2004b: 17). She expands this idea explaining that this type of reason prevented life from any form of transcendence; the existence of soul and spirit were denied, as well as the individual's need to transcend him/herself (2004b: 23). She criticizes this rationality for denying the possibility of self-engenderment that takes the self from an individual to a person, as argued in Persona y democracia (1958). For Zambrano, acknowledging and integrating this spiritual component of the human being into a wider, richer rationality is one of the elements that would foster the transition from an individual into a person with a fully socio-political projection. ${ }^{8}$ This is one of the reasons why Zambrano progressively chose to adopt a more mystical approach. In contrast, it is this enthronement of reason and its aseptic separation from life what she describes as the arrogance of reason.

In parallel with this, one of the common goals in all manifestations of Frankfurtian Critical Theory is the self-actualization of the individual. Moreover, for the members of the Institut, the actualization of individual freedom requires adopting a common praxis that is more than the result of the mere coordination of individual interests. This is to say that for Critical Theorists, just like for Zambrano, the self-actualization of the individual is only successful when it is linked to the selfactualization of all the other members of society, which is reminiscent of what Zambrano would refer to as becoming a person (see Honneth, 2004: 342-3). For her, becoming a person, as opposed to an individual, constitutes a moral and, ultimately, a political endeavour. She makes this point succinctly

\footnotetext{
7 The first edition was published under the title La Confesión: Género literario y método (1943). It was reedited in 1988 under the title La Confesión: Género literario, which includes modifications to this work that Zambrano herself made in 1965.

${ }^{8}$ Another parallel can be drawn here to the Frankfurt School. Although the members School differed on their approach to and assessment of religion, there is no doubt that they viewed it as a fundamental part of people's lifeworld and they were very much aware of the relationship between religion and reason, as well as between religion and politics. Despite their Marxist influence and their criticism of religion as ideology, influenced by their Jewish heritage, they engaged in critical debate with elements of religion and spirituality. Most notably, Benjamin provocatively argued that Marxism constitutes a secularization of the Judeo-Christian messianism; whereas, on the other hand, Horkheimer's later thought became increasingly concerned with transcendence.
} 
in "Delirio, esperanza y razón" (1959), ${ }^{9}$ where she explains how "la experiencia personal está implicada en la experiencia histórica; no cabe queriendo ser íntegramente persona, sustraerse a ella" (Zambrano 1996: 170). Being a person, much like Heidegger's Dasein, involves being-in-the-worldwith-others, which for Zambrano translates into taking responsibility and being politically active.

This goal of self-actualization reveals that the Frankfurt School is not only concerned with socio-political analysis, but, more primarily, that their criticism of instrumental reason as a socially deficient rationality is the result of the ethical core implied in Critical Theory (see Honneth, 2004: 338). However, despite this ethical motivation, they reject the possibility of a universal moral theory (see Honneth, 2004: 342). Likewise, Zambrano's efforts to develop an alternative rationality are the result of an epistemological imperative as much as an ethical one. This is to say that her interest in developing a rationality which integrates non-rational forms of knowledge emanates from the moral imperative to eliminate the sacrificial component from history. That is why one of the key aspects that Critical Theory and poetic reason have in common is that they are both inherently linked to a project of liberation, which is why they strive to go beyond the realm of theory in order to affect reality.

In fact, the distinctiveness of Critical Theory lies in that, far from being merely descriptive, its aim is to transform society, as opposed to uncritically reproducing it (see Kellner, 1989: 46; also Rush, 2004: 9). As Simone Chambers states, the aims of Critical Theory are: "to show the internal relationship between knowledge and experience [...], and to use the interconnectedness of knowledge and experience to break out of the given and project normative goals and ends" (2004: 221). Consequently, Critical Theory not only claims to be essentially different in its theoretical content but, more radically, also in its style and methodology, effectively constituting an alternative framework of rationality of its own right, so as to avoid becoming prey to its own criticism.

The methodology and goals of Critical Theory were first put forward by Horkheimer in his essay "Traditional and Critical Theory" (1937) and Marcuse's "Philosophy and Critical Theory" (1937). There, Marcuse establishes the difference between philosophy and Critical Theory in that while the former, being concerned with pure reason alone, can never conclude anything that was not already present in essence, the latter is anchored in different aspects of the material conditions for thought and perception, allegedly providing a genuine platform for social transformations. In Marcuse's words, "the real field of knowledge is not the given facts about things as they are, but the critical evaluation of them as a prelude to passing beyond their given form" (1955: 145). This is achieved by incorporating elements traditionally excluded from the realm of reason, such as subjectivity and praxis, and stressing the relationship between knowledge and experience, and even between knowledge and memory.

Likewise, Zambrano is also explicitly critical of any "pensamiento 'apriorístico' que sólo se descubre a sí mismo, su propia estructura" (1989a: 32). Specifically, she is critical of discursive

\footnotetext{
${ }^{9}$ Originally published in Nueva Revista Cubana (La Habana), it was compiled in 1996 by Jorge Luis Arcos as part of La cuba secreta y otros ensayos.
} 
reason. The term discursive comes from the Greek diánoia and it refers to the kind of reason which, based on the principle of causality, conceives the acquisition of knowledge only through inference; that is to say that its epistemology rests on the inference of new knowledge from pre-existing premises. The cornerstones of this discursive reason include Aristotelian logic, Cartesian reason, and the Enlightenment, which represents its cusp. Zambrano is critical of all of these forms of reason for being limited in their scope and, more crucially, for being limiting. As Elena Laurenzi explains, Zambrano is critical of analytical forms of thought specifically because they are unable to go beyond that which is already there (2004: 24). In contrast, she argues for the incorporation of elements traditionally banished from the confines of rationality, such as spirituality and intuition, while she also reclaims the value of elements considered contrary to reason, such as delirium. Hence, both Critical Theory and poetic reason rests upon a subversive, wider epistemological base, which does not exclude the mystical and the religious.

As part of their attempt not to fall prey to the dominant rationality, the style which Critical Theorists use to communicate can be considered the materialization of their methodology. This style, although idiosyncratic to each one of them, shares the same core aims and features; namely, the destabilisation of instrumental reason through the expression of complex and interrelated trains of thought by defying the linguistic limitations of lineal expression. Furthermore, this style of expression demands the engagement of the reader with the text; the reader no longer is a passive subject who absorbs information, but an active agent who strives to make sense of the text and of the society and ideology it discusses (see How, 2003: 2).

An example of this can be found in Adorno's texts, which are considered notoriously difficult as Edward Said puts it, "Adorno is exceptionally difficult to read, whether in his original German or in any number of translations. Jameson [in Late Marxism: Adorno, or, the Persistence of Dialectic (1990)] speaks very well about the sheer intelligence of his sentences, their incomparable refinement, their programmatically complex internal movement" (2002: 201). It must be stressed that the choice of this style is deliberate and obeys methodological reasons. As a result, many of Adorno's works "are self-conscious exercises in embodying the movement of ideas in negative dialectic in a style of philosophical writing" (Rush, 2004: 35). This becomes even more palpable in his later work which is characterized by his aphoristic and poetic expression. As Holger Brier indicates:

Adorno was no poet. [...] But his texts are informed by a poetic, itself informed, and not only historically, by a certain kind of music and poetry. Invariably, this does have implications for his style. [...] message and medium have to collapse into each other (2001: 113).

By integrating this poetic expression, Adorno aims to access and convey concepts which would otherwise be beyond the reach of the traditional philosophical, sociological or aesthetic discourse. This is reminiscent of what Zambrano does with her idiosyncratic use of language in her poetic reason. 
Zambrano pushes the terms of the relationship between philosophy and poetry by insisting on the benefits of bringing together both forms of knowledge. As she explains in "La destrucción de la filosofía en Nietzsche" (1945), "la poesía nació como ímpetu hacia la claridad desde esas zonas oscuras, por eso precede a la Filosofía -lenguaje meramente inteligible- y le ayuda a nacer" (2004a: 162). As her thought evolved, Zambrano increasingly developed and cultivated her poetic reason, whose features include contradiction, digression, symbolism, and metaphor. This type of language, while promoting the cross-fertilization between philosophy and poetry, effectively links language use to experientiality, consequently emphasizing the role of the reader in the process of the creation of meaning.

It is precisely the indeterminate quality of poetic language, the need to create meaning as opposed to extracting it, that accounts for the subversive value of Zambrano's poetic reason. Bearing testimony to the complexity of this form of rationality, in Notas de un método, Zambrano explains the following: "De la razón poética es muy difícil, casi imposible, hablar. Es como si hiciera morir y nacer a un tiempo; ser y no ser, silencio y palabra, sin caer en el martirio ni en el delirio" (1989b: 130). Beyond that, this quote also exemplifies that contradiction, digression, symbolism, and metaphor are all features that afford writer and reader the opportunity to break away with the shackles of the binary logic characteristic of Cartesian reason.

Moreover, by engaging in the rationality of poetic reason, the reader is also actively engaging in the process of self-actualization which facilitates becoming a person which is at the root of Zambrano's political vision, for only a society of persons can exercise the kind of integral democracy she envisions.

By the same token, the Institut's critique of the existing rationality and the socio-economic conditions it generates is hoped to lead to a process of enlightenment which will eventually achieve the liberation of the individual consciousness from the ideology it is subjected to, thus eventually liberating society as a whole. It is in this sense that their work is inherently political. However, the members of the School are all too aware of how difficult it is to overcome ideology.

The reason for their pessimism is that, as Adorno and Horkheimer put it, the fully administered society "embraces those at war with it by coordinating their consciousness with its own"" (Adorno, 1978: 206). In other words, although the aim of Critical Theory is liberating the individual from the all-encompassing ideology which constrains thought and possibility, for them, thought cannot be freed from ideology because the totally administered society absorbs and neutralizes criticism. More to the point, since ideology is inescapable, even that statement is made from an ideological standpoint. For this reason, their focus, as the term Critical Theory indicates, is precisely the aspect of critique.

The realization of the impossibility of escaping the existing co-ordinates of rationality, however, does not mean that their work is not political. As Chambers goes on to explain, "One of the ways of understanding their continued commitment to theory is to suggest that they replaced the question 'what is to be done?' with the much older one 'how should one live one's life?"' (2004: 
222). This is not to be understood as a withdrawal into theory. Instead, in a Socratian turn, they ultimately understand politics as paideia (see Chambers, 2004: 223). That is, their answer to the question "how to live?" is "teaching the good life" (Adorno, 1978: 15). This close link between education and politics is also essential in revealing the political component present in Zambrano's thought.

\section{Politics and Zambrano's political project}

There is no doubt that Zambrano engaged with politics at many levels during the years which go from 1927, when she joined the FUE, till the end of the Civil War. Her political engagement included her campaigning for the Republic, her experiences with party politics (particularly Acción Republicana on the one hand, and Frente Español on the other), her militant involvement with education, and her cultural and propagandistic efforts during the Civil War. However, there is little agreement on whether or not Zambrano engaged in politics after her exile in 1939. In order to answer this question, other questions must be addressed first, namely, what is politics? What constitutes politics for Zambrano? Did Zambrano ever sketch a political project?

Etymologically, the term politics comes from the Greek politikos, meaning "of citizens, pertaining to public life", which is derived from polites 'citizen' and from polis 'city-state'. Hence, politics is commonly conceived as being about agents or about structures of government. Politics is often understood in terms of relationships of power, authority, control, decision making, conflict resolution, resource allocation, or governance. Even debates about the proper definition of politics can be considered in themselves political. As György Lukács, borrowing Gottfried Keller's expression, goes as far as to argue that everything is politics (1964: 9). In short, there is no agreement amongst political theorists regarding the nature and boundaries of their object of study ${ }^{10}$.

Consequently, what is relevant for this discussion is what constitutes politics for Zambrano. In Horizonte del liberalismo (1930), Zambrano explicitly asks the question: "What is politics?" Her answer is: "Se hace política siempre que se piensa en dirigir la vida" (1930: 13). Immediately afterwards, she rejects the view that politics is will to power (1930: 13). Instead, she concludes: "Política es reforma, creación, revolución siempre, por tanto: Lucha -conjunción- entre el individuo y la vida" (1930: 14-15). In so far as Zambrano conceives politics as the intention to intervene and direct life, -echoing Aristotle- she concludes that politics may well be the most strictly human activity (1930: 15). Despite this, Zambrano does not consider every human action to be political. In fact, she specifically states -in an indirect reference to free will- that since politics is a human activity

\footnotetext{
${ }^{10}$ For a comprehensive analysis of different ways of interpreting the concept of politics, please refer to Adrian Leftwich's What is politics?: The activity and its study. Although first published in 1984, it has undergone numerous re-editions and in has been updated accordingly.
} 
its exercise is possible, as opposed to necessary; in other words, there is freedom of whether or not to act politically (1930: 16).

Zambrano's initial definition of politics as the thought, the intention to affect life reveals that her understanding politics is broad and closely linked to its etymological meaning. This is to say that, for her, politics, politikos, relates to the realm of public life, but it is inseparable from polites, from the citizen who becomes the agent of political change.

This ties in with Zambrano's critique of reason. What she is urging the reader to do in Horizonte del liberalismo is to become aware of the limitations of rationalism and reject it in favour of a more humanistic, life affirming rationality. To this end, Zambrano asserts that "la vida está por encima de la razón" (1930: 55). Consequently, she aspires to a form of rationality and a form of politics which, at its core, respects this hierarchy. She advocates for a humanistic reason which would not exclude intuition, passion, instinct, spirituality and faith. Nevertheless, she does not give up the benefits of the cultural side of liberalism. Instead, she concludes that a new liberalism is needed and demands an economic structure able to be on a par with what she describes as the spiritual postulates of liberalism (1930: 137). In essence, that political ideal is encapsulated in a cultural and spiritual liberalism which allows for the integral development of the person by avoiding the dangers of an overpowering materialism (see Abellán, 1998: 37, 259; see also Bundgård, 2005: 21-41).

The task is a gargantuan one. According to Zambrano, "hay que salvarlo todo. Cultura y democracia. Individuo y sociedad. Razón y sentimiento. Economía y libertad.” (1930: 127). She is not willing to give anything up. Having attempted to save everything, the real dilemma in the book is, as Jesús Moreno Sanz indicates, its vagueness, the lack of concrete solutions (1996a: 185). Tying in with her concept of politics as the intention to affect reality, Zambrano concludes that to resolve the contradiction of liberalism "habrá que atender, más que a los resultados, a los propósitos, a las intenciones" (1930: 128-29). By underscoring the role of intention, as opposed to actual results, she is positioning her discussing firmly on utopian territory. More than an effective plan of political action, her new liberalism constitutes a utopian desideratum. Nevertheless, Zambrano does not renounce to the project.

What already stems from this first book is that Zambrano's search for an alternative rationality is political at its roots. Here, she establishes a clear link between the horizon of political possibility and the established rationality. Her quest for a rationality that is not constrained by the limitations of rationalism is presented as a prerequisite for the development of a fair society -morally and economically-, which she identifies with a radical democracy, an idea which she would later elaborate at length in Persona y democracia (1958). Developing such a reason, one that in its humanist zeal also incorporates non-rational elements, would become Zambrano's life-long task. As part of this process, her mediating reason and her armed reason, both of which emerged during the 1930s, would, in time, give way to Zambrano's most original contribution: poetic reason. 
Going back to the question posed earlier: did Zambrano ever sketch a political project? The answer is undoubtedly yes. As Juan Fernando Ortega Muñoz affirms, "Ya por estas fechas tiene muy definido su ideal político, que la va a guiar toda su vida" (2004: 41). However, although inspired by this initial project, the tenor and intensity of Zambrano's political activity would vary over time.

\section{Zambrano's political commitment}

Despite Zambrano's disappointment with party politics and her refusal to participate in it after realizing her mistake of having created Frente Español in 1932, she did not give up her political engagement. Far from it, as Clare Nimmo puts is, "the political engagement [is] found at every turn in her writing" (1997: 893). What her resistance to commit to party politics and to a political programme accomplished is shifting the focus from the prescriptive social sphere to the more immediate personal realm; replacing the question "what should be done?" with "how should I lead my life?". Just like in the case of Critical Theorists, this is not to be understood as an inner withdrawal, but as an empowering and fully political stand. This is a personal political engagement, not because it renounces the social dimension of politics, but precisely because it understands the genuine need for it; a need which Zambrano does not believe that can be met merely through representation. Instead, genuine political involvement must reflect the acquisition of a personal political compromise of the kind she adopts, that is the result of a profound engagement with reality; what Laurenzi describes as "práctica tenaz del pensamiento como intervención en lo real" (2004: 14).

Influenced by her father -an educator by profession- and by the Krausist spirit that imbued Republican ideals, one of the ways Zambrano manifested this profound engagement with reality was through her involvement with education, which emerged as a political activity during the late 1920s and 1930s. Her activities in the Liga de Educación Social, the Pedagogical Missions, and countless other cultural initiatives are examples of this. Moreover, like the Frankfurt School, Zambrano perceived a link between education and politics, for she considered that only the former will enable the latter (see 1989a: 81). This is why a pedagogical commitment permeates much of her work. For this thinker, education -in the sense of paideia $^{l 1}$ - constitutes the framework that would allow and support the flourishing of the individual's potentialities, which would in turn lead to his/her full social and political participation. That is why paideia is an intrinsically political concept, in as much as it is expected to have an impact on the organization and practices of a given society by means of educating its people. Hence, education is more than the preparation for politics; it constitutes a political act in and of itself.

Based on all of the above, I would like to suggest here that Zambrano's interweaving of political and philosophical content goes well beyond 1939. In fact, I argue that her work is guided by

\footnotetext{
${ }^{11}$ She is not alone. Heirs to the Krausist tradition, many Republics award education a privileged role. As Antoni Mora argues that "los filósofos republicanos viven su idea de paideia. El aspecto pedagógico como impulso básico de la filosofía es bien común en todos ellos" (2001: 132).
} 
two core goals which go hand in hand and which are political at their root: a pedagogical mission -in the sense of paideia - and the development of an alternative rationality, poetic reason, that would overcome the contradictions and limitations of the reason of the Enlightenment and classical liberalism, while promoting a humanistic democracy, as first glimpsed in Horizonte del liberalismo.

So, in conclusion, what role did politics play in Zambrano's thought after 1939? In the light of all of the above, this paper contends the following: first, although there is no doubt that Zambrano abandoned her political militancy after 1939, she nevertheless continued to be committed to her political project after this point; second, her political project functioned as a compass, guiding the evolution of her reason, in search of the poetic reason whose germ had already been present since her early conversations with her father during the $1920 \mathrm{~s}^{12}$; and, third, her search for a new rationality constitutes a political endeavour in the same sense as Critical Theory is widely considered to be political in nature.

Whereas Zambrano developed most of her critique of reason and its consequences in her earlier work, as her thought matured, it progressively became more constructive. This can be seen in her promotion of the humanistic democracy she envisaged in Persona y democracia, which Moreno Sanz aptly describes as a radical social-democracy (1996: 69). Here, as Alberto Moreiras explains, Zambrano argues for a form of democracy which is grounded on the abandonment of the sacrificial structuration of history (2009: 171); a possibility which, although obliquely, she explores later on in El hombre y lo divino (1955), by -as Moreiras suggests- attempting to take politics beyond subjectivity and beyond sovereignty. According to Moreiras, in order to achieve this, Zambrano appeals to memory, to remembering the legacy of the disposed, of the vanquished, as an antidote to what Moreiras describes as the biopolitical subjectivation, "and hence the promise of an altogether different politics, of another beginning: the other side of sacrificial politics." (2009: 184) $)^{13}$ Like Adorno and, particularly, Benjamin, who defended the memory of the victims, Zambrano also deliberately cultivated an anamnestic reason aimed at challenging the historical discourse which is predicated on the assumption of continuous progress and the political establishment shaped and comprised by the winners. ${ }^{14}$ Examples of this can be found in Delirio $y$ destino (which although written in the early 1050s in was not first published until 1989a), Carta sobre el exilio (1961), and the prologue to the 1977 edition of Los intelectuales en el drama de España.

\footnotetext{
${ }^{12}$ In fact, José Luis Mora García argues the essence of what poetic reason would eventually become had already been sketched in writing by her father as early as the 1920s (1998: n.p.). Thus, Mora convincingly surmises that the emergence of this concept -as an ideal still unnamed- occurred in the dialogue between father and daughter. 13 Please see Moreiras's essay “The Last God: María Zambrano's Life Without Texture”, where he explains Zambrano's critical engagement with the political implications of Heidegger's ontology as well as shedding light on the implications of Zambrano's proposal for a democracy which no longer stands upon the foundations of sacrificial history (2009: 170-84).

${ }^{14}$ See Beatriz Caballero Rodríguez's paper “The Cathartic Exercise of Memory in María Zambrano's Delirio y destino" for a wider discussion of cathartic and political role of memory in Zambrano's writings, as well as her experimenting with delirium as a way to voice the memory of the vanquished (2004: 141-54).
} 
Having embarked upon the search for a rationality that would integrate reason and emotion, philosophy and poetry as argued in Filosofia y poesia (1939), her later work finally embodied such rationality in the form of poetic reason, in publications such as El sueño creador (1965), Claros del bosque (1977) and De la aurora (1986). It is this embracement of poetic reason, as well as her use of mystical and increasingly hermetic language, that has led to a frequent solipsistic interpretation of her writings, particularly her later work. Such reading of Zambrano should not be interpreted as being at odds with the political commitment which has been underlined throughout this essay. Instead, let us remember that one of the core features of poetic reason is that it is not absolute as a mode of expression, but rather, that it is pregnant with layers of meaning. This is one of the ways it challenges the linearity of Western reason and its foundations on binary logic. This is why in addition to taking the reader in an intimist and mystical journey into the inner depths of the human condition, poetic reason is also performing a political function. Zambrano's poetic reason stems from the premise that the democracy she aspires to in Persona y democracia starts only with the self-discovery that will turn the individual into a person capable of the compassion which comes from the realization that we all are being-in-the-world-with-others; and poetic reason is expected to serve to facilitate this. Lest not forget that poetic reason is not just poetic in the sense of poetry, but crucially also in the sense of poiesis, from the Greek, meaning to make, to create. In this sense, poetic reason can be thought of performative, in so far as it constitutes an engagement with reality such that by saying something is doing something. Like Critical Theory, poetic reason does not constitute a descriptive discourse, but a transformative one. In conclusion, what must be emphasized is that poetic reason does not represent the abandonment of politics, but the continuation and exercise of Zambrano's early political project.

\section{Bibliography}

Abellán, José Luis. 1998. El exilio filosófico en América; Los transterrados de 1939, Fondo de Cultura económica, Méjico.

Adorno, Theodor W. 1978. Minima Moralia, Verso, New York; London. . 2003. «Education after Auschwitz» in R. Tiedemann (ed.) Can One Live after Auschwitz?: A

Philosophical Reader, Stanford University Press, Stanford; Eurospan, London, pp.19-36.

Balibrea, Mari Paz. 2005. "Rethinking Spanish Republican Exile: An Introduction," Journal of Spanish Cultural Studies 6: 3-24.

Brier, Holger. 2001. "Thinking Adorno: The Necessity of Poetry”, in H. Briel and A. Kramer (eds), Practice: Adorno, Critical Theory and Cultural Studies, Peter Lang, New York; Oxford, pp.105-16.

Bronner, Stephen E. 2002. Of Critical Theory and its Theorists, Routledge, London and New York.

Bundgård, Ana. 2005. "El liberalismo espiritual de María Zambrano: Horizonte del liberalismo," Journal of Spanish Cultural Studies 6: 21-41. 
Caballero Rodríguez, Beatriz. "The Cathartic Exercise of Memory in María Zambrano's Delirio y destino," in S. Leggott, and R. Woods (eds), Memory and trauma in the postwar Spanish novel: revisiting the past, Bucknell University Press, Lewisburg, pp. 141-54.

Chambers, Simone. 2004. "The Politics of Critical Theory," in Fred Rush (ed.), The Cambridge Companion to Critical Theory, Cambridge University Press, Cambridge, pp. 219-249.

Gómez Sánchez, Carlos. 2004. "La Escuela de Frankfurt: J. Habermas,” in F. Vallespín (ed.) Historia de la teoría política, vol.6, Alianza, Madrid, pp.211-50.

Heller, Agnes. 2002. "The Frankfurt School," in J.T. Nealon \& C. Irr (eds) Rethinking the Frankfurt School: Alternative Legacies of Cultural Critique, SUNY, Albany, pp.207-21.

Honneth, Axel. 2004. "Social Pathology of Reason: On the Intellectual Legacy of Critical Theory" in Fred Rush (ed.), The Cambridge Companion to Critical Theory, Cambridge University Press, Cambridge, pp. 336-60.

Horkheimer, Max. 1973, Eclipse of Reason, Continuum, Nueva York.

How, Alan. 2003. Critical Theory, Palgrave Macmillan, Nueva York.

Kellner, Douglas, 1989, Critical Theory, Marxism and Modernity, Polity Press, Oxford.

Laurenzi, Elena. 2004. "María Zambrano: Una mujer 'filósofo'," in E. Laurenzi (ed.) María Zambrano: Nacer por sí misma, horas y HORAS, Madrid, pp.13-51.

Leftwich, Adrian, and Alex Callinicos. 1984. What is Politics?: The Activity and its Study. Oxford, England: B. Blackwell.

Lukács, György. 1964. Studies in European Realism. New York: Grosset and Dunlap.

Marcuse, Herbert. 1955. Reason and Revolution. Hegel and the Rise of Social Theory, Routledge y Kegan Paul, Londres y U.S.A.

Mora, Antoni. 2001. "Los filósofos de la República: La filosofía política del exilio del 39," in J.M. Balcells and J.A. Pérez Bowie (eds) El Exilio Cultural De La Guerra Civil (1936-1939), Aquilafuente, Salamanca, pp. 127-39.

Mora García, José Luis. 1998. "Introducción, edición y notas de los artículos y escritos de Blas Zambrano" in Blas J. Zambrano (1874-1938). Artículos, Relatos Y Otros Escritos. Badajoz: Diputación Provincial de Badajoz. Consulted in http://filosofia.org/aut/bza/index.htm 9 March 2014.

Moreiras, Alberto. 2009. “The Last God: María Zambrano's Life Without Texture,” in C. Strathausen, (ed.) A Leftist Ontology: Beyond Relativism and Identity Politics, University of Minnesota Press, Minneapolis, pp. 170-84.

Nimmo, Clare E. 1997. "The Poet and the Thinker: María Zambrano and Feminist Criticism," The Modern Language Review 92 (4): 893-902.

Ortega Muñoz, Juan Fernando. 2004. "Biografía", in María Zambrano: La aurora del pensamiento. Ortega Muñoz, Juan Fernando (ed.) Granada: Junta de Andalucia, Consejería de Cultura, pp. 25-103. 
Rasmussen, David. 2006. «Critical Theory: Horkheimer, Adorno, Habermas», in R. Kearney (ed.) Twentieth-Century Continental Philosophy, Routledge, London, pp. 254-89.

Rush, Fred, 2004, "Conceptual Foundations of Early Critical Theory" in Fred Rush (ed.), The Cambridge Companion to Critical Theory, Cambridge University Press, Cambridge, pp. 6-39.

Said, Edward. 2002. "Adorno as Lateness Itself” in Nigel C. Gibson y Andrew Rubin (eds.), Adorno: A Critical Reader, Blackwell, Oxford, pp. 193-208.

Soto Carrasco, David. 2010. "Historia y violencia: Walter Benjamin y María Zambrano", Thémata 43: 417-34.

Moreno Sanz, Jesús. 1996. "Introducción,” in J. Moreno Sanz (ed.) Horizonte del liberalismo, Morata, Madrid, pp.9-193.

Zambrano, María. 1930. Nuevo liberalismo, Morata, Madrid. . 1939. Pensamiento y poesía en la vida española, Casa de España en México, México. 1955. El hombre y lo divino. Mexico: Fondo de Cultura Económica. . 1961. "Carta sobre el exilio", Cuadernos del Congreso por la Libertad de la Cultura (París) 49 junio: $65-70$. . 1977. Los intelectuales en el drama de España, Hispamerca, Madrid. . 1989a. Delirio y destino: Los veinte años de una española, Mondadori, Madrid. . 1989b. Notas de un método, Madrid, Mondadori.

. 1996. "Delirio, esperanza y razón," in J.L. Arcos (ed.) La cuba secreta y otros ensayos, Endymión, Madrid, pp.164-71. . 2004a. Hacia un saber sobre el alma, Alianza, Madrid. .2004b. La confesión: Género literario, Siruela, Madrid. 